\title{
A Comparative Study of Upper Secondary School Biology Curricula in Two Countries: Finland and Nigeria
}

\author{
Emeka Sylvester Nwoke*, Anna Uitto, Jari Lavonen \\ Faculty of Educational Sciences, University of Helsinki, Finland
}

*Corresponding Author: emeka.nwoke@helsinki.fi

\section{ABSTRACT}

Scientific literacy (SL) has been recognized as the main goal of science curricula documents around the world; however, comparative international curriculum research is limited, especially with Western and African countries. To fill this gap, this study aimed to compare the coverage of SL competencies with the components of knowledge, attitudes, and contexts in the upper secondary school biology curricula of Finland and Nigeria. Content analysis was used as a method and a modified version of the SL framework of the Programme for International Student Assessment 2015 (OECD, 2016) was used to analyze the curricula. The results revealed that both curricula contain the main components of SL defined in the framework, scientific knowledge being the most prominent, followed by scientific competencies. Both curricula laid less emphasis on the interpretation competency and attitudes to science component. The curricula differed in the amount of attention paid to the different areas of SL components. The Finnish curriculum focused more on content knowledge, explaining phenomena scientifically and frontiers of science and technology, while in the Nigerian curriculum procedural knowledge, evaluation and design of scientific enquiry and natural resources as context were more emphasized. The results of this study are not only important to the European and African continents but to other parts of the world for the promotion SL in schools, also the findings reinforce the call on curriculum planers and science educators to ensure equal coverage of all the dimensions of SL in the school science curriculum if the next generation of the world is to be scientifically literate.

KEY WORDS: Upper secondary school; biology curriculum; scientific literacy; Finnish science education; Nigeria science education

\section{INTRODUCTION}

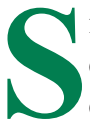
ince the introduction of the scientific literacy (SL) concept in 1958 by Hurd into the science education community, it has become a "pie in the sky" required by all citizens. Since then numerous science curriculum reforms have been implemented in various countries to accommodate SL as part of the aims of science education (DeBoer, 2000; Roberts, 2007; Roth and Lee, 2002) and a major policy thrust of most science curricula programmes around the world (e.g., AAAS, 1990; Jenkins, 2013; NRC, 2012).

Comparative study is normally concerned with cross-national analyses that seek to identify and describe curriculum documents in a comparable and standardized way, producing reports that describe curriculum standards, contents, and skills that outline the curriculum teachers are expected to deliver (Falkner et al., 2019). Moreover, globalization has brought about the teaching of the same science concepts in different classrooms across cultures (DeBoer, 2011; Koosimile and Suping, 2015; Lyons, 2006), for example, the STEM movement has brought about the teaching of science, technology, engineering, and mathematics practices in different countries. Despite the general agreement of the importance of knowledge-based, contextual-based and critical approaches in SL (Roberts and Bybee, 2014; Sjöström et al., 2017), large differences in the upper secondary school science curricula in different European, Asian, and African countries have been found (Vlaardinǵerbroek and Taylor, 2014). Because many historical, social, and educational issues affect curricula thinking, more detailed international comparative research focus is still needed.

Finland and Nigeria are two countries with major differences in science curricula (cf. Afemikhe and Imobekhai, 2014; Lavonen and Reinikainen, 2014). Historically, Finland has adopted a curriculum influenced by both the German Bildung-Didaktik and Anglo-American curriculum (Autio, 2014; Sjöström et al., 2017), Finland has a decentralized education system in which the local curriculum is prepared based on the national-level curriculum and the public entrusts teachers to add their input to the curriculum (Lavonen and Laaksonen, 2009).

Nigeria is a member of Anglophone sub-Saharan Africa, which has historically adopted Anglo-American curriculum theories due to colonial ties (Awofala, 2012), which for instance does not directly take the indigenous knowledge systems into account (Abah et al., 2015), but operates a centralized education system (Moja, 2000; Olibie et al., 2017), and the science curriculum is designed based on this central nature to guide teachers in educating their students.

Because of the cultural and historical differences, different education contexts and nature of curriculum (Adamson and Morris, 2014; Awofala, 2012; Coll et al., 2010; Jegede, 1997), one might expect differences in the school science curricula 
as well. For instance, in Finland curriculum objectives are written from the instructional perspective of the teachers as autonomous professionals who enjoy public trust to make inputs that guide the learning process (Autio, 2014; Westbury, 2000), thus, making it more teacher-oriented and contentfocused (cf. Tahirsylaj, 2019). However, curriculum objectives in Nigeria focus on students' performance and outcomes with limited teacher autonomy, depicting it as more institutionoriented and methods-focused (Westbury, 2000).

Moreover, biology is the favoured and preferred science subject among most upper secondary school students in both Nigeria (Afemikhe and Imobekhai, 2014) and Finland (Lavonen and Reinikainen, 2014; Uitto, 2014); hence, it was selected for the comparison of the upper secondary science curricula in this study. Therefore, we compared the two state level $\mathrm{K}-12$ biology curriculum documents with a focus on what is intended, to clarify whether certain characteristic patterns are inherent in each curriculum, which may reveal the differences and similarities between them in terms of subject matter knowledge, skills, attitudes, education contexts, and nature of curriculum (Adamson and Morris, 2014; Coll et al., 2010).

\section{LITERATURE REVIEW}

\section{The Science Curriculum}

The national level curriculum outlines a plan of intended goals, aims and objectives or description of learning outcomes at the national level, and it guides and regulates the educational processes (Oliva, 1997). Curriculum study is a broad area of research and focus, for example, on the relationship between curriculum and educational practice (Autio, 2014).

The curriculum is one of the central features of education, both in terms of organising education systems and in educational research. From the theoretical perspective, curriculum is a concept that has raised a lot of interest but no consensus about the definition has been achieved (Kelly, 2009; Schiro, 2013). However, the curriculum is a written document for managing the education process on a national, school or classroom levels; it is an official document to regulate what and how the schools teach in and outside their classrooms. The official curriculum, together with supporting materials, such as pedagogical guidelines and guidelines for the use of the different digi-tools is viewed as the intended curriculum (Van den Akker et al., 2010). According to Cuban (1992), the intended curriculum organises the body of knowledge and skills that students need to learn and illuminates, at least to some degree, the methods that will be used in teaching. Teachers interpret and modify the intended curriculum according to the needs in each context and this evolves into the implemented curriculum. The implemented curriculum is thus not necessarily identical to the intended curriculum.

Beyond the intended and implemented curriculum, teachers also convey messages that are not written in the curriculum that impacts the values, attitudes, knowledge, and behaviours of learners through the hidden curriculum. Therefore, a hidden curriculum refers to the unspoken or implicit values, behaviours, procedures, and norms that exist in the educational setting communicated to students through words and actions to make them better learners (Alusbaie, 2015; Schiro, 2013); however, this is not the focus of this article.

Moreover, the terms used to describe what a teacher should teach, or a student should learn varies in different traditions, for example, "goals" indicate general intentions of education. "Aims" breaks down goals into measurable behaviors. "Objectives" or "learning out-comes" are stated in narrower, precise, concrete, and measurable terms. In the Anglo-American curriculum tradition, objectives or learning outcomes indicate more what the learner should know or be able to do or have attained after teaching. By contrast, in the Bildung-Didatik tradition, aims guide teachers to plan their teaching (e.g., Autio, 2014; Sjöström et al., 2017; Westbury, 2000). Consequently, science curriculum can be summarized as a planned course of study in the natural sciences provided by the school to shape the students into intelligent and competent citizens capable of leading a useful life in the society and contributing to the well-being of others.

\section{Scientific Literacy}

Scientific literacy (SL) has become one of the most studied goals in science education (Bybee et al., 2009) that has received various considerations from many interest groups with its historical antecedent thoroughly discussed (DeBoer, 2000; Laugksch, 2000). Although SL is important in the science education process, it is also a controversial concept (Laugksch, 2000). However, despite the difficult nature of the concept, various researchers have discussed SL definitions and its constituents (e.g., Boujaoude, 2002; Bybee et al., 2009; Roberts, 2007; Roth and Lee, 2002).

Some studies equate SL to the acquisition of scientific knowledge in its various forms such as content, procedural or science process skills, and epistemic knowledge (Eisenhart et al., 1996; Van Eijck, 2010). More so, research has shown that science curricula documents around the world are dominated by science knowledge (Boujaoude, 2002; Upahi et al., 2017; Sothayapetch et al., 2013; Wang et al., 2019).

SL is also discussed in terms of science teaching and learning, focusing on the individual learning scientific "contents" and "science process skills" (Van Eijck, 2010). The expectations are for students to have the knowledge and skills needed in both the workplace and the society (DeBoer, 2000); such cognitive and scientific processes include content knowledge of science, posing scientific questions, problem solving, explaining phenomena scientifically, drawing evidencebased conclusions, and making justified decisions (Soobard and Rannikmae, 2014). Thus, science seeks to understand how individuals construct knowledge and how this leads to increased SL competencies through students' active participation (Van Eijck, 2010).

Another important dimension of SL is the context of learning. Research has shown that the context in which science is 
presented to learners is essential and should be reflected in school science curriculum (Lavonen and Laaksonen, 2009; Overmans et al., 2014). Contextual science education help students to attach values to the application of science and raise science interest (Hunsu et al., 2017), especially when such values impact their everyday lives.

\section{Attitudes toward Science Learning}

As a construct, attitude consists of many sub constructs reflecting personal feeling or opinion about something, for instance (school) science (Osborne et al., 2003). Attitudes toward science play an important role in science learning and consequently in SL because it determines an individual's interest in, attention to, and response to science and technology (Bybee et al., 2009). It is believed that a student's interest and motivation in science is a product of context, content, and activity; thus, interest in science topics increases if they are relevant to the learner's life (Elster, 2009). Lavonen and Laaksonen (2009) posited that interest in a subject affects the intensity and continuity of students' engagement in learning situations; but strong engagement deepens students' understanding.

\section{Finnish and Nigerian Education Contexts}

The worldview of SL in the Finnish context can be understood from the historical and educational perspectives of some European countries such as Russia, England, Sweden, and Germany (Simola, 2005). Finland is not such a multicultural or multilingual society compared to Nigeria; it is one of the countries that make up the European community; and shares common cultural practices that helped to shape European scientific worldviews characterized by open-mindedness, evidence-based conclusion, and documentation of facts which influence the science of today (Jegede, 1997).

In Finland, science education is strengthened by the Finnish education policy, whose prominent feature is the commitment to a vision of a knowledge-based society, educational equality, and teachers' autonomy (Lavonen, 2007).

The structure of the Finnish education system is such that there are 9 years comprehensive and compulsory education and then 3 or 4 more years of upper secondary education.

The purpose of science instructions at this level is to help students to understand the significance of science and technology as part of human culture and as a tool in modelling, predicting and explaining natural phenomena; it is also to support students' ability to participate in decision-making and problem-solving, development of interest towards science and a positive science-related self-concept (Lavonen and Reinikainen, 2014). Biology is studied as part of science education in grades one to four (FNBE, 2004). In grades five to six, biology is studied under the heading "biology and geography," while other natural sciences are studied as "chemistry and physics." However, in grades seven to nine and in upper secondary school; all-natural sciences including biology are studied as separate subjects.
The Finnish science curriculum emphasises identifying scientific issues in real life and using enough evidence in reasoning and supporting scientific claims and data (Lavonen, 2014; Lavonen and Laaksonen, 2009; OECD, 2007). However, a unique feature of the curriculum is the presentation of aims for teaching science - not description of learning outcomes (Lavonen, 2007).

Nigeria on the other hand, is both a multicultural and multilingual society; education in Nigeria has primarily taken place through apprenticeships before colonialization (Aina et al., 2019).

According to Aina et al. (2019), science teaching and learning in Nigeria dates back to the time of informal education characterized by storytelling, imitation, and lacked documentation. However, Mbajiorgu and Anolue (2000) argued that the Nigerian society is fast doing away with the beliefs that hinder scientific knowledge acquisition; thus, the country now shares the worldview of science and the epistemological beliefs that are common values of science. Therefore, the science education context in Nigeria is a mix of the traditional African culture - bedeviled by superstitious belief system built around witchcrafts, magic-medicine, taboos, reincarnation, and ancestors (Ogunniyi, 1987; Olorundare, 1988) and Western scientific views such as scientific method, creativity, science questioning, analysis, and interpretation of data (Wong and Hodson, 2008). As differences between Western and traditional African cultures have been reported in the literature (Aikenhead and Jegede, 1999), they are not the subject of this paper.

In Nigeria, education is regulated by the Federal Government; thereby centralizing education policy and curriculum design and implementation, the government places emphasis on the quality of education and established nationally acceptable standards and practices. Nigeria's national policy on education states the broad aim of secondary education in terms of learning outcomes, which is the preparation of citizens for useful living within the society (The Federal Republic of Nigeria, 2004).

This policy stipulates the 6-3-3-4 education system, now changed to 9-3-4 since the introduction of the Universal Basic Education (UBE) in 1999/2000; - 6 years of primary education and 3 years of junior secondary education that cumulates into 9 years of basic education, and 3 years of senior secondary education followed by 4 or more years of higher education (Olibie et al., 2017; Orij, 2011). The new senior secondary education curricula (SSEC) including biology was developed in 2006 and implemented in 2011; the SSEC was designed based on thematic approach and is spiral in nature, especially in content organisation (Afemikhe and Imobekhai, 2014; Omosewo and Akanmu, 2013; Orij, 2011). The biology curriculum in Nigeria is organized into four themes: the organisation of life, organisms at work, the organism and its environment, and continuity of life; the aims for biology learning at this level is to prepare students to acquire: adequate laboratory and field skills, meaningful and relevant science knowledge, ability to 
apply scientific knowledge to everyday life, and reasonable and functional scientific attitude (NERDC, 2008).

\section{RESEARCH PURPOSE AND STUDY QUESTIONS}

Despite the cultural and historical differences between European and Anglophone sub-Saharan African countries, comparative research on science curricula is largely lacking. This study strives to fill this gap, with the aim of examining the coverage of SL dimensions in the intended upper secondary school biology curricula in two different educational contexts: Finland and Nigeria. The goal is to understand the similarities and differences in how aspects of SL dimensions are presented in the upper secondary school biology curricula of both countries to shed light on intercultural studies. The following questions were asked:

1. What are the dimensions of SL, emphasized in the intended upper secondary school biology curricula in Finland and Nigeria?

2. What are the similarities and differences that exist in the SL dimensions of the intended upper secondary school biology curricula of the two countries?

\section{METHODS}

The major documents analysed were, the Finnish national core curriculum for upper secondary schools: biology (FNBE, 2003) which consists of 261 pages but only six pages focused on biology education and referred to as FHBC in this paper and the Nigerian senior secondary school biology curriculum (NERDC, 2008), a 71-page document referred to as NHBC in this paper. This study adopted the deductive content analysis approach (Neuendorf, 2002) and has been used by other researchers in analyzing curriculum documents (Sothayapetch et al., 2013; Wang et al., 2019); a modified PISA 2015 (Figure 1) framework (OECD, 2016) was used as an analysis tool.

One of the most well-known SL frameworks, which emphasises skills and competences, is the Program for International Student Assessment (PISA); originally used in international surveys (OECD, 2007; 2016). The PISA definition of SL lays emphasis on the use of scientific knowledge and willingness to use this knowledge (Attitude) in science processes (Competencies) and problems and issues (Contexts) in the real world (Figure 1).

Scientific knowledge or concepts constitute the links that aid understanding of related phenomena. The concepts used in the tasks are familiar ones relating to physics, chemistry, biology, and earth and space sciences but they are applied to the content of the items and not just recalled. The first framework included knowledge about science as part of the knowledge dimension; but the year 2013 framework introduced content, procedural and epistemic knowledge like the model employed in this study. Content knowledge is the use of science concepts in the three competencies. Procedural knowledge refers to how to do science; it involves awareness of the methods used by scientists to establish what we know and of the procedures that technologists and engineers use to design machines. Epistemic knowledge is defined as knowledge of the constructs and defining features essential to the process of knowledge building in science and their role in justifying the knowledge produced by science and its role in contributing to how we know what we know (Figure 1).

The second main dimension used in the content analysis focuses on scientific competencies which are centered on the ability to acquire, interpret and act on evidence. Three such processes present in PISA relate to: (i) describing, explaining and predicting scientific phenomena, (ii) evaluating and designing scientific enquiry, such as asking questions, planning and conducting investigations and understanding scientific investigation, and (iii) interpreting data and evidence scientifically and drawing evidence-based conclusions (Figure 1).

Contexts are another SL dimension utilized in the analysis and refers to real life issues; the PISA framework serves as guideline for scientifically literate persons in adulthood and includes an idea that the competencies described in it are useful in various problem-solving situations in adulthood (Bybee and McCrae, 2011) which include but not limited to: health and diseases, natural resources, environmental quality, hazards, and frontiers of science and technology relating to personal, local and global situations (not included in the analysis).

More so, attitude dimension was part of the analysis and are key components of an individual's science competence that include an individual's values, motivational orientations, and sense of self-efficacy. Attitudes and engagement with science are measured in some areas: support for scientific enquiry; self-belief as science learners; interest in science etc. and are important variables that determine the choices of students to either continue with science or reject it (Bennett and Hogarth, 2009; Palmer et al., 2017).

The PISA 2015 science framework (OECD, 2016) outlined four dimensions with components and subcomponents under each, for example scientific knowledge is classified into content, procedural and epistemic. We included scientific facts, concepts, principles and laws, hypothesis, models; recall of science information and discussion; labelled diagrams, pictures and drawings in the content knowledge subcomponent and did the same for the other dimensions of SL (see Appendix). Thus, the competencies require students to demonstrate their subject matter knowledge and cognitive skills, attitudes, values, and reasons for responding to sciencerelated problems in particular contexts to foster SL (LupionCobos et al., 2017), which help students to link scientific concepts to real-world situations (Bennett and Lubben., 2006; Gilbert, 2006).

The research retained the definitions of the four major SL dimensions of PISA 2015 but revised the definitions of the 


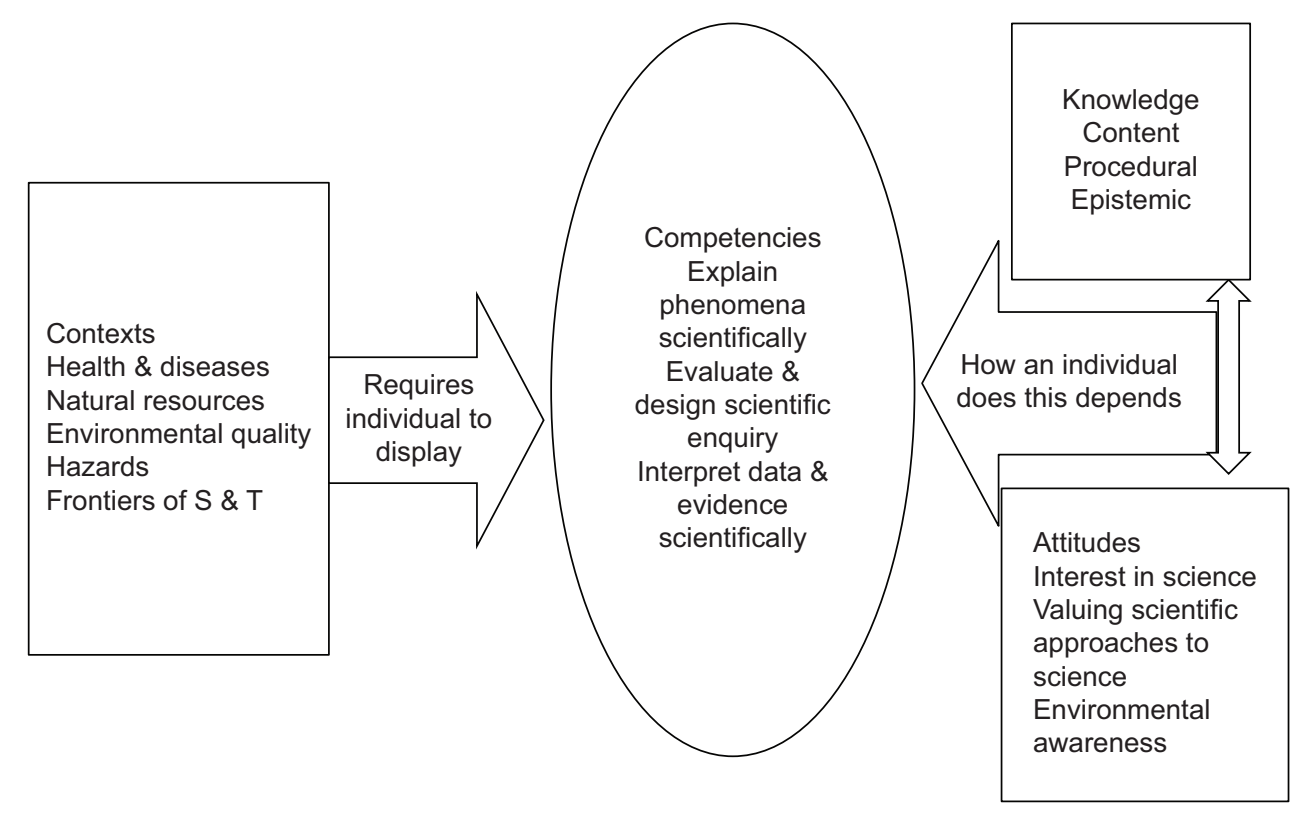

Figure 1: A Modified PISA 2015 Science Framework

subcomponents to be in line with biology education, making the coding process more systematic; units that were difficult to code were subjected to further discussion by the researchers. The first author wrote the definitions of the units (see Appendix), while the second and third authors made critical revisions with suggestions on changes to be made; the texts were coded as soon as agreement was reached. However, due to the difficulty in coding for the levels of contexts in both curricula because of overlapping statements across the major components of the analysis framework, they were dropped from the analysis.

The PISA framework was applied because it helped the researchers to bring to light the meaning of SL and identify its dimensions, and how these are reflected in the biology curricula (Soobard and Rannikmae, 2004). Secondly, due to globalization, most nations of the world are shifting from the traditional emphasis of science knowledge reproduction to transfer to real-world situations (Lupion-Cobos et al., 2017); hence, the framework helps to reveal the transfer mechanisms in biology education, as a function of both countries' education systems that prepare citizens for lifelong learning (Harlen, 2001). Thirdly, due to the fact that high school biology curricula differ in both countries; the PISA framework offers a neutral and internationally standardized frame to analyze and compare them. A brief description of the coding process is presented in the next section.

\section{Analysis of the Finnish and Nigerian curricula}

The official national level biology curricula documents of both nations were analyzed using the deductive content analysis (Neuendorf, 2002), first the curriculum texts were carefully read through to determine coding units based on the modified PISA 2015 framework. Next, the recognized units were deductively coded into each SL component and subcomponent based on the texts. All together four codes for the main components and fourteen codes for the sub-components were used (see Appendix).

Secondly, tables were made at the end of the analysis to calculate the frequency and percentage of each main component, and subcomponent as defined by the PISA 2015 science framework, and finally, the Chi-square statistical test tool was used to compare the FHBC and NHBC to determine how both differ on some aspects of SL themes. During the coding process, the authors recognized three comparable areas of the curriculum (general objectives, performance objectives, and evaluation guide) as texts of analysis. One full sentence or phrase was used as a unit of analysis, rather than word count that will not bring out the true intentions of the documents; sentences were replicated to put them into the appropriate subcomponent, because a sentence could belong to more than one sub-component. Examples of the coding process are provided in a subsequent section.

The authors aimed to increase the validity and reliability of the study by meeting several times to agree on the definitions of terms which resulted in clear objectives and sentences in the coding process. Moreover, the authors made trial coding and compared the coding to test the definitions of the code. The coders independently coded the texts during the coding process to ensure the reliability of the process; the percentage of agreement and Cohen's kappa are shown in Table 1, while Table 2 shows examples of the content analysis procedure.

\section{RESULTS}

The numerical and percentage distributions of SL dimensions in the general and specific objectives and evaluation guide of science teaching in the Finnish and Nigerian curricula are presented in tables' three to seven. From the analysis, the NHBC had 2212 units belonging to specific SL components and 1148 units had no components, compared to 309 units 
in the FHBC belonging to specific components and 159 units without components. This shows that the NHBC has

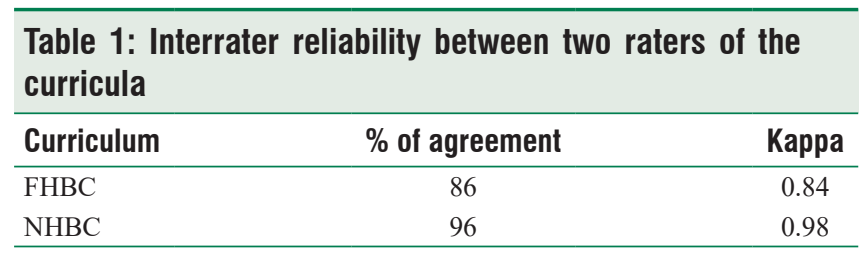

\section{Table 2: Examples of content analysis procedure}

\begin{tabular}{|c|c|}
\hline \multicolumn{2}{|c|}{ Knowledge component } \\
\hline Content & $\begin{array}{l}\text { The objectives of the course are for students } \\
\text { to: understand the significance of cells as the } \\
\text { basic units of life (FNBE, 2003, p. 135) }\end{array}$ \\
\hline Procedural & $\begin{array}{l}\text { Students observe the experiment and make } \\
\text { inferences. (NERDC, 2008, p. 11) }\end{array}$ \\
\hline Epistemic & $\begin{array}{l}\text { Be capable of assessing the opportunities, } \\
\text { risks and ethical problems involved in } \\
\text { the development of biotechnology and of } \\
\text { making justified solutions based on these in } \\
\text { their everyday lives. (FNBE, 2003, p. 139) }\end{array}$ \\
\hline
\end{tabular}

Scientific competencies component

Explain phenomena scientifically

Evaluate and design scientific enquiry

Explain the ability of cells to detect and respond to external stimuli. (NERDC, 2008, p. 7)

Be familiar with genetic screening and identification methods and with the main features of gene transfer techniques (FNBE, 2003, p. 139)

Interpret data and evidence Measure and record growth of a given scientifically microorganism from a prepared culture, plot a growth curve and interpret it. (NERDC, 2008, p. 22)

Contexts component Health and diseases

Students note the effects of pests and diseases on plants and animals in the farm (NERDC, 2008, p. 19)

Natural resources

Acquaint themselves with Finnish ecosystems and their special characteristics and familiarize themselves with human modified ecosystems (FNBE, 2003, p. 136)

Environmental quality

Students develop their environmental literacy, understand their responsibility for the state of the environment and know how to act in accordance with the principles of sustainable development (FNBE, 2003, p. 137)

Attitude component Interest in science

Valuing scientific approaches to enquiry

Proven interest in different areas of biology may also be considered as part of assessment (FNBE, 2003, p. 134)

Students to demonstrate by experiment, factors that affect growth (NERDC, 2008, p. 7)

Environmental awareness Students develop their environmental literacy, understand their responsibility for the state of the environment and know how to act in accordance with the principles of sustainable development (FNBE, 2003, p. 137) about 7-times more texts than the FHBC, probably due to the descriptions of learning outcomes in clear terms.

Table 3 shows that the main components of SL are emphasized in a similar manner in both curricula, as shown by the frequency and percentage distributions in both curricula; there is no significant statistical difference between them $\left(\chi^{2}[3, \mathrm{n}=2521]=4.2, \rho=0.25\right)$. Both curricula are dominated by scientific knowledge.

Similarly, both curricula emphasized the three types of scientific knowledge (Table 4) in a similar fashion; content knowledge constitutes the most visible portion followed by procedural knowledge, while epistemic knowledge is the least emphasized. However, the FHBC had more content knowledge statements than NHBC $(76.9 \%$ vs. $61.5 \%)$, on the other hand, the FHBC had fewer number of procedural knowledge statements than NHBC. Furthermore, the FHBC emphasized more of epistemic knowledge (3.4\%) than NHBC (1.2\%), nevertheless, both figures were considered low. Yet there was a statistically significant difference between the two curricula relating to the distribution of scientific knowledge components $\left(\chi^{2}[2, \mathrm{n}=950]=16.4, \rho<0.05\right)$.

The two curricula showed that both countries had a similar desire to develop scientific competencies in students but were expressed in different forms. The distribution of the three competencies between the curricula was statistically significant, $\left(\chi^{2}[2, \mathrm{n}=887]=26.1, \rho<0.05\right)($ Table 5). The FHBC emphasized more on the "explain" component compared to the NHBC, which emphasized more on the "inquiry" component than the FHBC. But in the "interpret" component the FHBC ranked higher compared to the NHBC (7.7\% vs. $3.9 \%)$.

The two countries demonstrated similar intention to contextualise biology education to make learning meaningful

\begin{tabular}{lccc}
\hline $\begin{array}{l}\text { Table 3: Comparison of Numerical and Percentage } \\
\text { Distributions of Scientific Literacy Themes }\end{array}$ \\
\hline $\begin{array}{l}\text { Curricula components } \\
\text { of scientific literacy }\end{array}$ & FHBC (\%) & NHBC (\%) & Total \\
\hline Scientific knowledge & $117(37.9)$ & $833(37.7)$ & 950 \\
Scientific competencies & $117(37.9)$ & $770(34.8)$ & 887 \\
Context of learning & $41(13.2)$ & $273(12.3)$ & 314 \\
Attitudes to science & $34(11)$ & $336(15.2)$ & 370 \\
Total & 309 & 2212 & 2521 \\
\hline
\end{tabular}

\begin{tabular}{|c|c|c|c|}
\hline $\begin{array}{l}\text { Curricula components of } \\
\text { scientific knowledge }\end{array}$ & FHBC (\%) & NHBC (\%) & Total \\
\hline Content knowledge & $90(76.9)$ & $512(61.5)$ & 602 \\
\hline Procedural knowledge & $23(19.7)$ & $311(37.3)$ & 334 \\
\hline Epistemic knowledge & $4(3.4)$ & $10(1.2)$ & 14 \\
\hline Total & 117 & 833 & 950 \\
\hline
\end{tabular}


to students; although this component had the lowest number of statements (Table 6), however, it showed that the statements were statistically significant $\left(\chi^{2}[4, n=314]=42.9, \rho<0.05\right)$ across the five components. The highest components highlighted in the FHBC were environmental quality, frontiers of science and technology and health and diseases, while hazards and natural resources ranked lowest ( $2.4 \%$ vs. $14.6 \%$ ). In the NHBC, the trend changed slightly, with environmental quality ranking highest followed by natural resources and health and diseases, while hazards and frontiers of science and technology ranked lowest (1.8\% vs. $2.2 \%)$, however, both countries focused on the environment as the context of meaningful learning.

The analysis showed that the FHBC and NHBC placed considerable emphasis on valuing scientific approaches to science, although the NHBC showed a greater degree of emphasis (Table 7). On the other hand, the FHBC placed the least emphasis on the interest in science compared to the NHBC. Environmental awareness was the second most emphasized component in the FHBC (41.2\%), compared to the NHBC which was the least emphasized (14.9\%). These observed differences in the distribution of attitudes between both curricula were statistically significant, $\left(\chi^{2}[2\right.$, $\mathrm{n}=370]=16.5, \rho<0.05)$.

\section{Table 5: Comparison of numerical and percentage} distributions of scientific competencies components

\begin{tabular}{lccc}
\hline $\begin{array}{l}\text { Curricula components of scientific } \\
\text { competencies }\end{array}$ & FHBC (\%) & NHBC (\%) & Total \\
\hline Explain phenomena scientifically & $91(77.8)$ & $446(57.9)$ & 537 \\
Evaluate and design scientific enquiry & $17(14.5)$ & $294(38.2)$ & 311 \\
Interpret data and evidence scientifically & $9(7.7)$ & $30(3.9)$ & 39 \\
Total & 117 & 770 & 887 \\
\hline
\end{tabular}

Table 6: Comparison of numerical and percentage distributions of contexts of learning components

\begin{tabular}{lccc}
\hline $\begin{array}{l}\text { Curricula components of context of } \\
\text { learning }\end{array}$ & FHBC (\%) & NHBC (\%) & Total \\
\hline Health and diseases & $7(17.1)$ & $55(20.1)$ & 62 \\
Natural resources & $6(14.6)$ & $70(25.6)$ & 76 \\
Environmental quality & $16(39)$ & $137(50.2)$ & 153 \\
Hazards & $1(2.4)$ & $5(1.8)$ & 6 \\
Frontiers of science and technology & $11(26.8)$ & $6(2.2)$ & 17 \\
Total & 41 & 273 & 314 \\
\hline
\end{tabular}

\begin{tabular}{|c|c|c|c|}
\hline Curricula components of attitudes & FHBC (\%) & NHBC (\%) & Total \\
\hline Interest in science & $3(8.8)$ & $87(25.9)$ & 90 \\
\hline Valuing scientific approaches to science & $17(50 \%)$ & $199(59.2 \%)$ & 216 \\
\hline Environmental awareness & $14(41.2 \%)$ & $50(14.9)$ & 64 \\
\hline Total & 34 & 336 & 370 \\
\hline
\end{tabular}

\section{DISCUSSIONS}

\section{Finnish and Nigerian Biology Curricula in the European} Framework of Science Education

The purpose of this study was to compare the upper secondary school biology curricula in Finland and Nigeria for the coverage of SL themes based on the PISA 2015 science framework to highlight curricula similarities and differences, as a contribution to intercultural studies. The results of this study show that one of the intentions of the two curricula is to educate citizens to be scientifically literate and this aligns with the visions of PISA 2015 framework (OECD, 2016).

Based on quantitative results, both biology curricula follow a similar trend; scientific knowledge was the most emphasized in the two curricula, followed by competencies, attitudes and contexts, which are consistent with similar research (Boujaoude, 2002; Upahi et al., 2017; Sothayapetch et al., 2013; Wang et al., 2019). This implies that the FHBC and NHBC emphasise PISA SL dimensions almost equally (Table 3), acknowledging that scientific knowledge, competencies, contexts, and attitudes are ingredients of SL needed to effectively process science information in classroom teaching and learning. Also, this supports the model of PISA science framework (Figure 1) used in this analysis depicting the process of SL; for individuals to exhibit the scientific competencies required for successful living, they need the understanding of science concepts combined with positive attitudes toward science and the recognition of socio-scientific issues in the society.

The similarity of the result lend support to the globalization movement and its effect on science curriculum documents across cultures (Adamson and Morris, 2014; Coll et al., 2010; DeBoer, 2011; Koosimile and Suping, 2015) and highlights learning of the same science concepts in school classrooms of different countries (Lyons, 2006); the results further show that formal science education in Nigeria could be interpreted as Anglo-American in outlook and lacked African indigenous contents after many decades of independence (Abah et al., 2015).

Similarities and Differences between the Finnish and Nigerian Curricula

When the curricula are compared on the subcomponent levels some differences emerge. In Finland, the biology curriculum shows that the subject matter is dominated by procedural knowledge and skills (Lavonen \& Reinikainen, 2014); and the subject contributes to the building of a knowledge-based society (Lavonen, 2007); where individuals are expected to take decisions concerning their well being and that of the larger society based on the repertoire of subject matter knowledge they have, but the results in this study (see Table 4) contradicts the findings of Lavonen and Reinikainen (2014). Conversely, science procedural knowledge is more favored in the Nigerian curriculum, probably due to the nature of the curriculum that favors the Anglo-American tradition where aims are clearly stated in terms of students learning outcomes 
(Tahirsylaj, 2019). The two curricula acknowledge that students need the various forms of science knowledge to pass competent judgement on scientific issues and explain natural phenomena, which aligns with the PISA framework (OECD, 2016); but failed to express these types of knowledge in equal proportions - epistemic knowledge being the least emphasized.

Furthermore, the Finnish curriculum places more emphasis on the "explain" competency (involves the application of content knowledge), followed by the "inquiry" competency ( $77.8 \%$ vs. $7.7 \%$ (Table 5) which is an inclination to the American type of curriculum thinking (Wang et al., 2019); while in Nigeria, the focus is on the "evaluate/design" competency which could explain higher percentage of procedural knowledge in the curriculum.

Both curricula placed less emphasis on the "interpret" competency domain which is worrisome at this level of education where students are expected to focus on higher level competencies like data interpretation that require skills in inductive and deductive reasoning, transformation of data to tables and graphs and or extraction of information from representations such as charts, graphs and tables, construction of arguments and explanations based on data. Giving such low attention to scientific practices by the two curricula will make the goal of educating citizens with adequate scientific competencies and SL difficult.

Furthermore, the quantitative data from this research (Table 6) show that both curricula emphasized less on contextualized biology education; this tends to negate the importance of contextual learning in science seen as a vehicle that links scientific concepts to real-world situations (Bennett and Lubben, 2006; Gilbert, 2006) and the benefit of contextualized teaching known for its supportive role in the development of interest (Hunsu et al., 2017). Despite this, the differences between the curricula regarding the distribution of subcomponents in the learning context is significant $\left(\chi^{2}[4\right.$, $\mathrm{n}=314]=42.9, \rho<0.05)$. The NHBC seems to emphasise more context of learning over the FHBC except in the frontiers of science and technology. This could imply, that Nigeria as a developing country still lacks the innovative capability required in science and technology, which may affect the study of science in the country. Furthermore, it can be an indicator of why Finland is among the developed economies of the world, due to the role played by science and technology in the social and economic development of the nation. However, this assertion needs further investigation before a conclusion could be reached. As the results of this study has shown; context of learning may not be the only curricula factor that has made Finland very successful in PISA evaluations over the years; but a combination of other factors has been the driving force in the country's success (Lavonen and Laaksonen, 2009), and Nigerian curriculum designers could learn from this experience.

Attitudes to science are another SL dimension that had low number of statements in the two curricula. Nevertheless, there are differences in emphasis in the subcomponents as the NHBC have higher expression of "interest in science" over FHBC (25.9\% vs. $8.8 \%$ ) (Table 7$)$. This implies that the curricula encourage students to develop positive feelings when studying science. Furthermore, this can produce longlasting effects on their knowledge of science concepts and can increase engagement in learning. Moreover, analyses of the curricula showed that both countries placed considerable emphasis on "valuing scientific approaches to science"- an indication that students should engage in scientific enquiry in an organized manner to generate reliable data; however, this subcomponent has a slight higher expression in the NHBC over the Finnish curriculum (59.2\% vs 50\%). But the "environmental awareness" subcomponent is less preferred in the Nigerian curriculum.

According to Lavonen and Laaksonen, (2009), Osborne et al. (2003), Palmer et al. (2017), attitude plays a significant role in students' interest, sense of self-efficacy, attention, and response to science and technology and could be a determinant of their science learning and future involvements in the subject.

Meanwhile, this study aligns with the PISA SL framework (OECD , 2016) which defines three competencies that describe the use of science subject knowledge in its various forms, and willingness (attitude) to use this knowledge in different contexts (situations).

\section{CONCLUSION}

Our findings show that irrespective of curriculum traditions, the PISA SL themes were reflected in both the Finnish and Nigerian curricula. However, as shown by the results of comparisons, there were variations. Contexts of education or nature of curriculum could result in differences between curricula. For example, the Finnish curriculum integrates the German Bildung-didaktik and Anglo-American features - scientific knowledge make up a major proportion of it without carefully structured list of broad thematic learning concepts but formulated from the instructional perspective of the teachers as professionals that add inputs to the curriculum to educate the students. In contrast, Nigeria strictly adopts the AngloAmerican curriculum tradition, where learning objectives are broadly stated in terms of students learning outcomes which may reflect the dominance of procedural knowledge statements in the curriculum because they were based on what teachers are expected to do in the teaching-learning process. However, the similarity of the curricula in many areas points to the convergence of the two curricula traditions which could explain the role of globalization in curriculum implementation across nations (DeBoer, 2011; Koosimile and Suping, 2015) leading to the teaching of the same science concepts in schools.

Finally, we recommend some potential areas of research in the future; firstly, a comparative study focusing on both the upper secondary school and the basic/junior school curricula. Secondly, the effects of the newly introduced curriculum in Finland should be compared with the old one. However, we 
intend to compare the curricula as learning material in the second part of this study.

\section{REFERENCES}

AAAS. (1990). Science for All Americans. Washington, D.C., United States: American Association for the Advancement of Science.

Abah, J., Mashebe, P., \& Denuga, D.D. (2015). Prospect of integrating African indigenous knowledge systems into teaching of sciences in Africa. American Journal of Educational Research, 3(6), 668-673.

Adamson, B., Morris P. (2014) Comparing Curricula. In: Bray M., Adamson, B., Mason, M., (Eds.) Comparative Education Research: Approaches and Methods. Berlin: Springer. pp. 309-332.

Afemikhe, O.A., \& Imobekhai, S.Y. (2014). Nigeria. In: Vlaardingerbroek, B., \& Taylor, N., (Eds.), Issues in Upper Secondary Science Education: Comparative Studies. London, United Kingdom: Palgrave. pp. 62-69.

Aikenhead, G., \& Jegede, O. (1999). Cross-cultural science education: A cognitive explanation of a cultural phenomenon. Journal of Research in Science Teaching, 36(3), 269-287.

Aina, J.K., Nathaniel, N.G., \& Ayodele, M.O. (2019). The trajectories of science education in Nigeria and its challenge to sustainable development. Cross-Current: An International Peer-Reviewed Journal on Humanities and Social Sciences, 5(3), 53-61.

Alusbaie, M.A. (2015). Hidden curriculum as one of the current issues of curriculum. Journal of Education and Practice, 6(33), 125-128.

Autio, T. (2014). The internationalisation of curriculum research. In: Pinar, W., (Ed.), International Handbook of Curriculum Research. Milton Park, Abingdon-on-Thames: Routledge. pp. 17-31.

Awofala, A.O. (2012). An analysis of the 9-year basic education mathematics curriculum in Nigeria. Acta Didactica Napocensia, 5(1), 17-27.

Bennett, J., \& Hogarth, S. (2009). Would you want to talk to a scientist at a party? High school students' attitudes to school science and to science. International Journal of Science Education, 31(14), 1975-1998.

Bennett, J., \& Lubben, F. (2006). Context-based chemistry: The Salters approach. International Journal of Science Education, 28(9), 999-1015.

Boujaoude, S. (2002). Balance of scientific literacy themes in science curricula: The case of Lebanon. International Journal of Science Education, 24(2), 139-156.

Bybee, R., \& McCrae, B. (2011). Scientific literacy and student attitudes: Perspectives from PISA 2006 science. International Journal of Science Education, 33(1), 7-26.

Bybee, R., McCrae, B., \& Laurie, R. (2009). PISA 2006: An assessment of scientific literacy. Journal of Research in Science Teaching, 46(8), 865-883.

Chiappetta, E.L., \& Fillman, D.A. (2007). Analysis of five high school biology textbooks used in the United States for inclusion of the nature of science. Journal of Science Education, 29(15), 1847-1868.

Coll, R.K., Dahsah, C., \& Faikhamta, C. (2010). The influence of educational context on science learning: A cross-national analysis of PISA. Research in Science and Technological Education, 28(1), 3-24.

Cuban, L. (1992). Curriculum stability and change. In: Jackson, P.W., (Ed.), Handbook of Research on Curriculum. Basingstoke, United Kingdom: Macmillan. pp. 216-247.

DeBoer, G.E. (2000). Scientific literacy: Another look at its historical and contemporary meanings and its relationship to science education reform. Journal of Research in Science Teaching, 37(6), 582-601.

DeBoer, G.E. (2011). The globalisation of science education. Journal of Research in Science Teaching, 48(6), 567-591.

Eisenhart, M., Finkel, E., \& Marrion, S. (1996). Creating the conditions for scientific literacy. American Educational Research Journal, $33,261-295$

Elster, D. (2009). Biology in context: teacher's professional development in learning communities. Journal of Biological Education, 43(2), 53-61.

Falkner, K., Sentence, S., Vivian, R., Barksdale, S., Busuttil, L., Cole, E., Liebe, C., Maiorana, F., McGill, M.M., \& Quille, K. (2019). An International Comparison of K-12 Computer Science Education Intended and Enacted Curriculum. In: Proceedings of Koli Callin '19: 19 th $^{\text {Koli }}$ Calling International Conference on Computing Education Research (Koli Calling '19).
Finnish National Board of Education (FNBE). (2003). National Core Curriculum for Upper Secondary Schools: Biology. Finnish National Board of Education.

Finnish National Board of Education (FNBE). (2004). National Core Curriculum for Basic Education. Finnish National Board of Education.

Gilbert, J.K. (2006). On the nature of "context" in chemical education. International Journal of Science Education, 28(9), 957-976.

Harlen, W. (2001). The assessment of scientific literacy in the OECD/PISA project. Studies in Science Education, 36, 79-104.

Hunsu, N.J., Adesope, O., \& Van Wie, B.J. (2017). Engendering situational interest through innovative instruction in an engineering classroom:

What really mattered? Instructional Science, 45(6), 789-804.

Hurd, P.H. (1958). Science literacy: Its meaning for American schools. Educational Leadership, 16(1), 13-16.

Jegede, O.J. (1997). School science and the development of scientific culture: A review of contemporary science education in Africa. International Journal of Science Education, 19(1), 1-20.

Jenkins, E.W. (2013). The "nature of science" in the school curriculum: The great survivor. Journal of Curriculum Studies, 45(2), 132-151.

Kelly, A.V. (2009). The Curriculum: Theory and Practice. Thousand Oaks, California: Sage Publication.

Koosimile, A.T., \& Suping, S.M. (2015). An examination of the influence of globalisation on science education in Anglophone Sub-Saharan Africa. International Journal of Science Education, 37(14), 2358-2385.

Laugksch, R.C. (2000). Scientific literacy: A conceptual overview. Science Education, 84, 71-94.

Lavonen, J. (2007). National science education standards and assessment in Finland. In: Waddington, D., Nentwig, P., \& Sascha, S., (Eds.), Making it comparable. Münster, Germany: Waxmann. pp. 101-126.

Lavonen, J. (2014). A new Finnish national core curriculum for basic education (2014) and technology as an integrated tool for learning. In: Niemi, H., Multisilta, J., Lipponen, L., \& Vivitsou, M., (Eds.), Finnish Innovations and Technologies in Schools: A Guide towards New Ecosystems of Learning. Rotterdam, Netherlands: Sense Publishers. pp. 321-32.

Lavonen, J., \& Laaksonen, S. (2009). Context of teaching and learning school science in Finland: Reflections on PISA 2006 results. Journal of Research in Science Teaching, 46(8), 922-944.

Lavonen, J., \& Reinikainen, P. (2014). Finland. In: Vlaardingerbroek, B., \& Taylor, N. (Eds.), Issues in Upper Secondary Science Education: Comparative Perspectives. London, United Kingdom: Palgrave. pp. 20-30.

Lupion-Cobos, T., Lopez-Castilla, R., \& Blanco-Lopez, A. (2017). What do science teachers think about developing scientific competences through context-based teaching? A case study. International Journal of Science Education, 39(7), 937-963.

Lyons, T. (2006). Different countries, same science classes: Students' experiences of school science in their own words. International Journal of Science Education, 28(6), 591-613.

Mbajiorgu, N., \& Anolue, R. (2000). Students' perceptions about the epistemology of science: A comparison of some Nigerian and Canadian students. African Journal of Research in Mathematics, Science and Technology Education, 4(1), 57-69.

Moja, T. (2000). Nigeria Education Sector Analysis: An Analytical Synthesis of Performance and Main Issues. A World Bank Report.

Neuendorf, K. (2002). The Content Analysis Guidebook. Thousand Oaks, California: Sage Publication.

Nigerian Educational Research and Development Council (NERDC). (2008). Senior Secondary Biology Curriculum. Nigerian Educational Research and Development Council.

NRC. (2012). A Framework for K-12 Science Education. Washington, DC: The National Academies Press.

OECD. (2007). PISA 2006: Science Competencies for Tomorrow's World. Paris, France: Organisation for Economic Cooperation and Development.

OECD. (2016). PISA 2015. Assessment and Analytical Framework: Science, Reading, Mathematics, and Financial Literacy. Paris, France: Organisation for Economic Cooperation and Development. 
Ogunniyi, M. (1987). Conceptions of traditional cosmological ideas among literate and non-literate Nigerians. Journal of Research in Science Teaching, 24(2), 107-117.

Olibie, E.I., Egboka, P.N., \& Ofojebe, W.N. (2017). Secondary education policy and curriculum provisions in Nigeria: Matters arising and enhancement strategies. International Journal of Library and Educational Science, 3(1), 53-66.

Oliva, P. (1997). The Curriculum: Theoretical Dimensions. Harlow: Longman.

Olorundare, S. (1988). Scientific literacy in Nigeria: The role of science education programmes. International Journal of Science Education, 10(2), 151-158.

Omosewo, E., \& Akanmu, A. (2013). Evolution of functional basic and senior secondary education in Nigeria: Implications for effective implementation. Journal of Education and Practice, 4(22), 73-79.

Orij, N.S. (2011). The New Senior Secondary School Curricula: Prospects and Challenges for Achieving the Millennium Development Goals. $8^{\text {th }}$ Annual Conference on Educational Crisis and Millennium Development Goals in Nigeria. Primary and Tertiary Teacher Education Association of Nigeria. pp. 1-13.

Osborne, J., Simon, S., \& Collins, S. (2003). Attitudes towards science: A review of the literature and its implications. International Journal of Science Education, 25(9), 1049-1079.

Overmans, M., Vermunt, J.D., Meijer, P.C., Bulte, A.M., \& Brekelmans, M. (2014). Students' perceptions of teaching in context-based and traditional chemistry classrooms: Comparing content, learning activities, and interpersonal perspectives. International Journal of Science Education, 36(11), 1871-1901.

Palmer, T.A., Burke, P.F., \& Aubusson, P. (2017). Why school students choose and reject science: A study of the factors that students consider when selecting subjects. International Journal of Science Education, 39(6), 645-662.

Roberts, D.A. (2007). Scientific literacy/science literacy. In: Abell, S.K., \& Lederman, N.G. (Eds.), Handbook of Research on Science Education. Mahwah: Lawrence Erlbaum Associates. pp. 729-780.

Roberts, D.A., \& Bybee, W.R. (2014). Scientific literacy, science literacy, and science education. In: Lederman, N.G., \& Abel, S.K., (Eds.), Handbook of Research on Science Education. Milton Park, Abingdonon-Thames: Routledge. pp. 545-558.

Roth, W.M., \& Lee, S. (2002). Scientific literacy as a collective praxis. Public Understanding of Science, 11, 33-56.

Schiro, M.S. (2013). Curriculum Theory: Conflicting Visions and Enduring Concerns. $2^{\text {nd }}$ ed. Thousand Oaks, California: Sage Publications.

Simola, H. (2005). The Finnish miracle of PISA: historical and sociological remarks on teaching and teacher education. Comparative Education, 41(4), 455-470.
Sjöström, J., Frerichs, N., Zuin, V.G., \& Eilks, I. (2017). Use of the concept of Bildung in the international science education literature, its potential, and implications for teaching and learning. Studies in Science Education, 53(2), 165-192.

Soobard, R., \& Rannikmae, M. (2014). Upper secondary students' selfperceptions of both their competence in problem solving, decision making and reasoning within science subjects and their future careers. Journal of Baltic Science Education, 13(4), 544-558.

Sothayapetch, P., Lavonen, J., \& Juuti, K. (2013). A comparative analysis of PISA scientific literacy framework in Finnish and Thai science curricula. Science Education International, 24(1), 78-97.

Tahirsylaj, A. (2019). Teacher autonomy and responsibility variation and association with student performance in Didaktik and curriculum traditions. Journal of Curriculum Studies, 51(2), 162-184.

The Federal Republic of Nigeria. (2004). National Policy on Education. Thrissur, Kerala: Educational Research and Development Council.

Uitto, A. (2014). Interest, attitudes and self-efficacy beliefs explaining upper-secondary school students' orientation towards biology-related careers. International Journal of Science and Mathematics Education, $12,1425-1444$.

Upahi, J.E., Gbadamosi, R., \& Boniface, V.E. (2017). Scientific literacy themes coverage in the Nigerian senior school chemistry curriculum. Journal of Turkish Science Education, 14(2), 52-64.

Van den Akker, J., Fasoglio, D., \& Mulder, H. (2010). A Curriculum Perspective on Plurilingual Education. Strasbourg, France: Council of Europe.

Van Eijck, M. (2010). Addressing the dynamics of science curricular reform for scientific literacy: The case of genomics. International Journal of Science Education, 32(18), 2429-2449.

Vlaardinǵerbroek, B., \& Taylor, N., (Eds.) (2014). Issues in Upper Secondary Science Education: Comparative Perspective. Basingstoke, United Kingdom: Macmillan.

Wang, Y., Lavonen, J., \& Tirri, K. (2019). An assessment of how scientific literacy-related aims are actualised in the national primary science curricula in China and Finland. International Journal of Science Education, 41(11), 1435-1456.

Westbury, I. (2000). Teaching as a reflective practice: What might Didaktik teach curriculum? In: Hopman, S., Riquarts, K., \& Westbury, I., (Eds.), Teaching as a Reflective Practice: The German Didaktik Tradition. Mahwah, NJ: Lawrence Erlbaum Associates. pp. 15-39.

Wong, S.L., \& Hodson, D. (2008). From the horse's mouth: What scientists say about scientific investigation and scientific knowledge. Science Education, 93, 109-130.

\section{APPENDIX}

The table below shows the description of the sub dimensions used for coding the main dimensions of scientific literacy (SL) as used in this study; some of the descriptors were used by Chiappetta and Fillman (2007) to analyze scientific literacy themes in biology textbooks, however, the sub dimensions: science as a way of investigating and science as a way of thinking were integrated into one (procedural knowledge); the authors also generated some descriptors following the definitions of SL themes in the PISA (2015) science framework operationalized in this study. 


\begin{tabular}{|c|c|c|}
\hline $\begin{array}{l}\text { SL main } \\
\text { dimensions }\end{array}$ & $\begin{array}{l}\text { SL sub } \\
\text { dimensions and } \\
\text { codes }\end{array}$ & Sentences/phrases and words to guide the coding process \\
\hline \multirow{23}{*}{$\begin{array}{l}\text { Scientific } \\
\text { knowledge }\end{array}$} & \multirow{6}{*}{$\begin{array}{l}\text { Content knowledge } \\
\text { (K1) }\end{array}$} & The analysis checks each of the sub dimensions if the intent of the curricula is to present \\
\hline & & • Facts, concepts, principles and laws. \\
\hline & & • Hypotheses, theories, and models. \\
\hline & & - Ask students to recall knowledge or information. \\
\hline & & • Ask students to discuss biological phenomenon. \\
\hline & & - Labelled diagrams, pictures \\
\hline & \multirow{12}{*}{$\begin{array}{l}\text { Procedural } \\
\text { knowledge (K2) }\end{array}$} & - Questions/statements accessing manipulative skills. \\
\hline & & - Learning using materials. \\
\hline & & - Experiments showing inquiry as a good way to acquire new knowledge \\
\hline & & • Learning using tables, graphs, and charts. \\
\hline & & • Learning by making calculations. \\
\hline & & - Statements making students to reason out an answer. \\
\hline & & - Make students to participate in a thought experiment. \\
\hline & & - Statements that make students to get information from different sources e.g., internet. \\
\hline & & - Statements/activities illustrating the empirical basis of science. \\
\hline & & - Activities that gives evidence and proof to scientific investigation. \\
\hline & & - Statements/activities showing cause and effect relationships. \\
\hline & & - Statements and activities that present methods of science and problem solving. \\
\hline & $\begin{array}{l}\text { Epistemic } \\
\text { knowledge (K3) }\end{array}$ & $\begin{array}{l}\text { - Statements showing the role of the nature of science (e.g., tentativeness of science) in scientific discoveries/ } \\
\text { knowledge }\end{array}$ \\
\hline & & $\begin{array}{l}\text { - Statements showing the functions of the different forms of empirical inquiry and objectivity as a good way to } \\
\text { acquire new knowledge. }\end{array}$ \\
\hline & & $\begin{array}{l}\text { - Statements showing the role of data in justifying the many claims/reasoning in science e.g., deductive and } \\
\text { inductive. }\end{array}$ \\
\hline & & - Statements showing the role of argumentation in scientific knowledge. \\
\hline & & - Statements showing the importance of how scientists discovered or experimented/historical development of ideas \\
\hline \multirow{16}{*}{$\begin{array}{l}\text { Science } \\
\text { competencies }\end{array}$} & \multirow{5}{*}{$\begin{array}{l}\text { Explain } \\
\text { phenomena } \\
\text { scientifically }(\mathrm{C} 1)\end{array}$} & • Describe natural events i.e., offer explanatory hypotheses \\
\hline & & - Use of biological vocabularies (appropriate scientific knowledge) to explain natural phenomena/and or hypotheses. \\
\hline & & • Discusses simple biological experiments. \\
\hline & & - Statements describing simple biological process diagrams/models. \\
\hline & & • Explain the potential implications of scientific knowledge for society. \\
\hline & \multirow{6}{*}{$\begin{array}{l}\text { Evaluate and } \\
\text { design scientific } \\
\text { enquiry (C2) }\end{array}$} & • Activities encouraging hands-on exercises/identify the question explored in each scientific study. \\
\hline & & $\begin{array}{l}\text { - Diagrams, pictures, and drawings/statements showing how scientists experimented in the past and propose a way } \\
\text { of exploring a given question scientifically. }\end{array}$ \\
\hline & & $\begin{array}{l}\text { - Activities that encourage both individual and group discoveries/evaluate ways of exploring a given question } \\
\text { scientifically. }\end{array}$ \\
\hline & & - Activities that encourage the documentation of experimental procedures and dissemination of information. \\
\hline & & - Activities that help students to engage in thought experiments and problem-solving techniques. \\
\hline & & - Plan and carry out simple biology experiments and ensure the reliability and objectivity of data. \\
\hline & \multirow{5}{*}{$\begin{array}{l}\text { Interprete data } \\
\text { and evidence } \\
\text { scientifically (C3) }\end{array}$} & $\begin{array}{l}\text { - Activities that encourage students to develop skills to analyze and evaluate claims, arguments, evidence from } \\
\text { different sources e.g., newspapers, journal, and internet. }\end{array}$ \\
\hline & & $\begin{array}{l}\text { - Activities that encourage students to develop skills to analyze and interpret data and draw appropriate scientific } \\
\text { conclusions. }\end{array}$ \\
\hline & & $\begin{array}{l}\text { - Activities that encourage students to develop skills to give appropriate interpretation to graphical representation/ } \\
\text { charts/transform data from one representation to another. }\end{array}$ \\
\hline & & - Activities encouraging students to identify the assumptions, evidence and reasoning in science-related texts. \\
\hline & & $\begin{array}{l}\text { - Encourage students to distinguish between arguments which are based on scientific evidence and theory and those } \\
\text { based on other considerations }\end{array}$ \\
\hline \multirow[t]{7}{*}{ Contexts } & \multirow{7}{*}{$\begin{array}{l}\text { Health and } \\
\text { diseases (CT1) }\end{array}$} & - Discusses health and diseases of animals and plants \\
\hline & & - Discusses issues of maintenance of health \\
\hline & & • Discusses accidents \\
\hline & & - Discusses nutrition and food choices \\
\hline & & • Emphasises control of diseases \\
\hline & & - Emphasises social transmission of diseases \\
\hline & & • Emphasises safety measures \\
\hline
\end{tabular}


Natural resources (CT2)

Environmental quality (CT3)

Hazards (CT4)

Frontiers of science and technology (CT5)

Attitudes (A1)

Valuing scientific approaches to science (A2)

Environmental awareness (A3)
- Emphasises how to maintain ecology/consumption of materials and energy

- Emphasises the maintenance of human populations

- Emphasises security of species

- Discusses the effects of food production, distribution and energy supply in the ecosystem/understand the ecosystem

- Emphasises renewable and non-renewable natural systems

- Emphasises environmentally friendly actions such as use and disposal of materials (human activities)

- Discusses air, water, and land pollutions

- Emphasises the effects of population distribution on the environment and species relationships

- Discusses the impact of environmental factors on the health of species

- Discussions on biodiversity, variation, ecological sustainability, pollution control

- Emphasises on production and loss of soil/biomass

- Emphasis on risk assessments

- Impacts of climate change e.g., earthquakes, severe weather, erosion

- Impacts of biological and chemical hazards on the environment

- Impacts of modern communication on the environment

- Discussion on the interrelationship between science, technology and society

- Applications of science and technology

- Discussion of issues of genes and genetic modification

- Extinction of species

- Advantages and disadvantages of science and technology on the society

- Ethics that control scientists

- Statements encouraging students to show curiosity in biology/science-related issues and endeavors

- A willingness to acquire additional biology knowledge and skills, using variety of resources and methods

- Motivational statements/activities encouraging students to consider biology-related careers

- Activities that will increase student's self-efficacy like planning and carrying out experiments/field work frequently

- Statements encouraging the appreciation of biology and science products

- Emphasizing engagement in enquiry-based scientific activities (generating evidence) for explaining the natural world

- Emphasizing the scientific approach i.e., data generation (problem solving)

- Activities leading students to critical thinking i.e., valuing criticism

- Seeking scientific information using various sources e.g., internet, library

- Documentation and publication of scientific findings

- Statements showing the needs for environmental protection/effects of human activities on the ecosystem

- Discussion of environmental protection practices

- Discussion of climate change on living organisms

- Emphasizing concern for the environment and sustainable living

- A disposition to take and promote environmentally sustainable behaviors

- Awareness of environmental issues 